\title{
Native trees provide more benefits than exotic trees when ecosystem services are weighted in Santiago, Chile
}

\author{
Gabriela Arcos-LeBert ${ }^{1} \cdot$ Tamara Aravena-Hidalgo $^{1} \cdot$ Javier A. Figueroa $^{2} \cdot$ Fabián M. Jaksic $^{3} \cdot$ Sergio A. Castro $^{1}$ (I)
}

Received: 18 January 2021 / Accepted: 30 April 2021 / Published online: 29 May 2021

(c) The Author(s) 2021

\begin{abstract}
Urban forests are conformed by a variable representation of native and exotic species. Because these species differ in the morpho-functional traits that possess, they may have a differential participation in the provision of ecosystem services in cities. Here, we compare ecosystem services inferred from morpho-functional traits of native and exotic tree species present in Santiago, Chile. Five traits associated with ecosystem services valuation $\left(V_{i}\right)$ were scored ( 1 versus 0$)$, and compared between native and exotic tree species, weighting those ecosystem services according to multi-criteria decision analysis procedure (MCDA). We found that native and exotic species did not have significant differences in the ecosystem services provided to urban dwellers $(F=1.2 ; P>0.05)$; but these results were obtained when ecosystem services were not weighted according to their demand in Santiago. When weights were pondered, native species provided more ecosystem services than did exotic trees $(F=7.1 ; P<0.008)$. Complementarily, we also found that the ecosystem services ranked for native and exotic species did not correlate with their spatial distribution (occupancy, $O_{i}$ ). These results highlight the need to use criteria based on ecosystem services to tree planting in Santiago, prioritizing native species because, in comparison to exotic ones, they provide more ecosystem services demanded city dwellers.
\end{abstract}

Keywords Alien tree $\cdot$ Ecosystem service $\cdot$ Morpho-functional trait $\cdot$ Tree appraisal $\cdot$ Urban tree

\section{Introduction}

Communicated by Giuliano Maselli Locosselli .

Sergio A. Castro

sergio.castro@usach.cl

Gabriela Arcos-LeBert

gaba.arcos@gmail.com

Tamara Aravena-Hidalgo

aravena.tamara@gmail.com

Javier A. Figueroa

javier.figueroa@ucentral.cl

Fabián M. Jaksic

fjaksic@bio.puc.cl

1 Laboratorio de Ecología y Biodiversidad, Facultad de Química y Biología, Universidad de Santiago de Chile, Alameda Bernardo O’Higgins 3363, Santiago, Chile

2 Instituto de la Facultad de Ingeniería y Arquitectura, Universidad Central de Chile, Avenida Santa Isabel 1186, Santiago, Chile

3 Center of Applied Ecology and Sustainability (CAPES), Pontificia Universidad Católica de Chile, Alameda Bernardo O’Higgins 340, Santiago, Chile
Urban areas are undergoing a rapid expansion worldwide that results in complex patterns of landscape configuration and species composition (Millennium Ecosystem Assessment 2005). These transformations demand adjustments of the provision of ecosystem services-i.e., those services associated with human well-being that come from biodiversity (MEA 2005)—-toward favoring inhabitants (Güneralp et al. 2013). In this context, for example, it is considered that having an adequate green infrastructure design can help maintain and maximize the ecosystem and socioeconomic services affecting city dwellers (James et al. 2009; Soto et al. 2018), improving life quality and urban sustainability (Tzoulas et al. 2007; Panagopoulos et al. 2016).

Urban trees are important components of the green infrastructure, because they are associated with the provision of diverse ecosystem services (Roy et al. 2012; GómezBaggethun and Barton 2013; McBride 2017). These services include mitigation of pollution, microclimatic regulation, water regulation, soil quality, and the production of edible fruits (Nowak and Dwyer, 2007; Fisher et al. 2009; 
Escobedo et al. 2011). As tree species differ in their characteristics and biological attributes (e.g., height, foliage, lifespan, etc.), they participate and contribute differentially in the provision of these ecosystem services (Diaz and Cabido 2001; Roy et al. 2012). Therefore, knowing the environmental needs demanded by a particular city, it may be possible to implement tree planting strategies using tree species that better satisfy these needs (Saebo et al. 2003). Along this line, a key question is which of the ecosystem services demanded by a given city are covered by current urban trees.

Urban forests around the world are composed of a mix of native and exotic species (Alvey 2006; Aronson et al. 2015; Gaertner et al. 2017), with exotic species dominating urban green spaces in some regions, such as South American cities (dos Santos et al. 2010; Santilli et al. 2018; Jaksic and Castro 2020). In this context, a controversy has emerged about the role of native and exotic tree species (Dearnorn and Kark 2010; Conway et al. 2019). On the one hand, some studies promote the use of native trees based mainly on conservation purposes (Sagoff 2005, 2011; Dobbs et al. 2011; Capotorti et al. 2015; Oldfield et al. 2015), while others recommend to take advantage of the ecosystem services provided by tree species, regardless of their biogeographical origin (Sjöman et al. 2016; Potgieter et al. 2017; Riley et al. 2018; Vaz et al. 2018). Therefore, a first step toward making better decisions about native and/or exotic tree species in cities, requires a comparison of ecosystem services provided by these different species (Riley et al. 2018; Conway et al. 2019) to determine if they differentially satisfy the ecosystem services demanded by a particular city (Grote et al. 2016; Conway et al. 2019). Several methods for tree valuation (i.e., appraisal) have been used to determine the specific monetary value of standing trees, attending to tree and forest measurements and health-related variables (e.g., diameter, age, trunk basal area, etc.) and growing conditions (streets, avenues, parks, etc.) in cities (Watson 2002; Grande-Ortiz et al. 2012; Roy et al. 2012; Ponce-Donoso et al. 2017). Nevertheless, these approaches emphasize the economic cost/benefit ratio, paying little attention to ecosystem services provided by these species. Complementarily, an operational and useful approach is based on inferring ecosystem services from the morpho-functional traits of plants (Diaz and Cabido 2001). Indeed, there is growing evidence showing that morphofunctional traits determine ecosystem functioning, including the ecosystem services provided to the well-being of city dwellers (Casanoves et al. 2011; Kattge et al. 2011; Grote et al. 2016; Núñez-Florez et al. 2019).

Santiago is located in the Chilean mediterranean region, also known as central Chile. This region is considered a center of floristic diversity and a biodiversity hotspot of global relevance because it harbors approximately 3500 native plant species, $50 \%$ of which are endemic (Myers et al. 2000). Specifically, in central Chile there are 88 native tree species, 76 (86\%) of which are endemic (Rodríguez-Ríos et al. 2006), but these native species are poorly represented within the cities of the region, including Santiago (Escobedo et al. 2006, 2016; Figueroa et al. 2016; Hernández and Villaseñor 2018; Santilli et al. 2018). Indeed, the low representation of native trees in central Chilean cities is striking for some authors (Pauchard and Barbosa 2013; Figueroa et al. 2016; Santilli et al. 2018). Interestingly, the native and exotic tree species in Santiago differ in various morpho-functional traits, which are easily associated with ecosystem services rendered (Hoffmann 1995; Rodríguez-Ríos et al. 2006). For instance, native trees are mainly evergreen species, with sclerophyllous foliage and fleshy fruits, while exotic trees show winter deciduous and broadleaved foliage, and nonfleshy fruits (Hoffmann 1995; Rodríguez-Ríos et al. 2006). Therefore, sustainable planning of the urban forests in Santiago requires identifying morpho-functional traits associated with the ecosystem services provided by native and exotic tree species.

Based on the characterization of five morpho-functional traits of 171 tree species in Santiago, we infer their relative contribution to the provision of ecosystem services. Then, we weight this contribution according to the prioritized requirements for this city (ACHIPPA 2012), seeking an answer to two main questions: (1) Do native and exotic tree species differ in the ecosystem services they provide in Santiago? and (2) Is there a relationship between the representation of trees in Santiago and their contribution to ecosystem services?

\section{Methods}

\section{Study city}

Santiago is the political-administrative capital of Chile. Currently, it has approximately 6,900,000 inhabitants, an area of $8378 \mathrm{~km}^{2}$, and an altitude of about $500 \mathrm{~m}$ asl. According to DWUA (2019), Santiago is the seventh most densified city in Latin America (CEPALSTAT 2020), ranking among the 50 most agglomerated cities of the world (DWUA 2019). This city has a temperate mediterranean climate, characterized by cool and rainy winters, and dry and warm summers (Luebert and Pliscoff 2006). Due to the reduced altitude variation $(<200 \mathrm{~m})$ and its location between two mountain ranges, the climatic conditions in Santiago show a reduced spatial variation (see Mcphee et al. 2013).

\section{Species, spatial occupancy and biogeographic origins}

An exhaustive tree species list was obtained from floristic sampling (Figueroa et al. 2016; Santilli et al. 2018) and 
specialized publications about urban trees in Santiago (Hoffmann 1995; Rodríguez et al. 2006; Alvarado et al. 2013). Thus, a total of 171 species were recognized in Santiago, 21 native and 150 exotics were included in our study. In addition, we obtained the spatial occupancy per species $\left(O_{i}\right)$ from our floristic sampling carried out in Santiago (Figueroa et al. 2016; Santilli et al. 2018). This sampling consisted of the randomized disposition of 200 sites within Santiago, which were visited between 2012 and 2013 (see details in Figueroa et al. 2016). At these sites, we recorded the tree species present in three types of habitats: sidewalks $(n=200)$, squares (200) and empty places (200). Then, the spatial occupancy was calculated as the percentage of sampled sites occupied by each species from total set of sampled sites (600 sites); thus, the spatial occupancy was uses as a comparative indicator among species of the spatial distribution in Santiago.

The biogeographic origin of each species was extracted from Rodríguez-Ríos et al. (2006) and Santilli et al. (2018). The 'native' species were those whose natural distribution correspond to central Chile, while 'exotic' species were those that have been introduced from other countries. Because of the small number of native species recorded in Santiago $(n=21)$, the six 'native extralimital' species (sensu La Sorte and McKinney 2006) were treated as native taxa in Santiago; these species were A. araucana (Mol.) Koch, originally distributed in southern Chile $\left(37^{\circ}-40^{\circ} \mathrm{S}\right.$; Rodríguez et al. 2006), outside the geographic range of central Chile $\left(30^{\circ} 36^{\circ}\right.$; Armesto et al. 2007); meanwhile, Aextoxicon punctatum Ruiz et Pav., Schinus areira L., Schinus latifolius (Gillies ex Lindl.) Engl, Schinus polygamous (Cav.) Cabrera, and Sophora cassioides (Phil.) Sparre show populations in central Chile, whose original range does not include the geographical location of Santiago (Rodríguez et al. 2006).

\section{Ecosystem services and morpho-functional traits}

First, we recognized five ecosystem services that trees in Santiago may fulfill; these services were considered among the most relevant and demanded in the city (see ACHIPPA 2012): (a) mitigation of atmospheric particulate matter during autumn and fall; (b) reduction of irrigation, (c) provision of quality shade during spring and summer; (d) maintenance of nitrified soil; and (e) production of edible fruits. Then, for each 171 tree species we checked for morpho-functional attributes associated with the satisfaction of these services.

Because of the absence of empirical and/or quantitative data for many tree species in Santiago, we used a binary categorization and grossly assigned services to two possible states: high $(=1)$ and low $(=0)$ contribution or benefit for urban dwellers. It is important to note that we prefer to use this binary code because it yields standardized comparisons between completely different attributes, thus buffering effects due to the wide variation in scale and taxonomic ranges (Grote et al. 2016; Núñez-Florez et al. 2019). Because three attributes were continuous among species (e.g., hydric requirement; foliage volume and density; nodulation capability; and nitrogen-fixation; see Table 1), the binary code was applied considering the modal value as class-mark for both categories.

These morpho-functional traits and their respective character states were (Table 1): (a) Type of foliage: perennial (1) or deciduous foliage (0), contributing high and low annual retention capacity of atmospheric particulate matter, respectively (Rodríguez-Ríos et al. 2006); (b) Hydric requirement: low (1) or high irrigation requirements (0), related to the water economy; hydric requirements were obtained from ACHIPPA (2012); (c) Foliage architecture: high (1) and low (0) shade quality based on shade production in spring-summer, following to ACHIPPA (2012); (d) Nodulation capability and nitrogen-fixation: good maintenance of organic soils (1) and tree species without this capacity (0), based on the maintenance of soil quality (Tedersoo et al. 2017); (e) Edible fruit: trees producing edible (1) and non-edible fruits (0) that potentially are consumed by urban dwellers (Rodríguez-Ríos et al. 2006).

Table 1 List of morpho-functional traits of urban trees, character stages (assigned scores) and ecosystem services-associated literature sources are given

\begin{tabular}{|c|c|c|c|}
\hline Morpho-functional traits & Character stage and scores & Sources & Ecosystem service associated in towns \\
\hline 1. Type of foliage & Perennial (1) and caducifolious foliage (0) & Rodríguez et al. (2006) & $\begin{array}{l}\text { Mitigation of atmospheric particulate } \\
\text { matter, during autumn and fall }\end{array}$ \\
\hline 2. Hydric requirements & High (0) and low (1) water consumption & ACHIPPA (2012) & Water economy \\
\hline 3. Foliage architecture & $\begin{array}{l}\text { A real projection of the foliage shade High (1) } \\
\text { and low (0) shade quality }\end{array}$ & ACHIPPA (2012) & $\begin{array}{l}\text { Shade quality and production during } \\
\text { spring and summer }\end{array}$ \\
\hline $\begin{array}{l}\text { 4. Nodulation capability } \\
\text { and nitrogen-fixation }\end{array}$ & $\begin{array}{l}\text { With nodulation (1) and without nodulation } \\
\text { capability ( } 0)\end{array}$ & Tedersoo et al. (2017) & Maintenance of soil quality \\
\hline 5. Fruit type & $\begin{array}{l}\text { Production of edible fruit to urban dwellers (1) } \\
\text { and inedible fruit }(0)\end{array}$ & Rodríguez-Ríos et al. (2006) & Production of edible fruits \\
\hline
\end{tabular}




\section{Weighting the ecosystem services $\left(w_{i}\right)$}

The ecosystem services weights $\left(w_{i}\right)$ were determined by the analytic hierarchical process (AHP; Saaty 1980), a multicriteria decision procedure used to assign priorities among factors contrasted in pairs (Golden et al. 1989). This tool provides a useful approach to cope with the complexity resulting from trade-offs between multiple objectives that cannot be attained at the same time (Belton and Stewart 2002). In addition, this approach allows including a hierarchical valuation upon several criteria mathematically expressed as weights that modulate the importance of some criteria over others (Mustajoki et al. 2020).

The paired comparisons were carried out by consulting five experts about the importance that they assigned to the five ecosystem services under study (Table 2). Basically, experts were individually asked to assign priorities to the paired combination of ecosystem services (Saaty 1980). The expert could assign a value equal to " 1 " when he/she considered that both services (A and B; Table 2) had equal importance; " 3 " when service A is slightly more important than B (Table 2); "5" when service A is moderately more important than B (Table 2); "7" when service A is greatly more important than the other (Table 2); and " 9 " when service A is much more important than B (Table 2). Once the individual judgments of the experts were obtained, the relative weights of each criterion were normalized and calculated in a column vector that indicates the prioritized criteria (see Saaty 1980). Thus, we obtained a hierarchy proportionally weighting each ecosystem service ( $w_{i}$; see Table 3 ) with the greatest demand or need to satisfy. All weights showed a consistency index of 0.95 , denoting that the weighting procedure was robust.

\section{Assigning ecosystem valuation $\left(V_{i}\right)$ to tree species and analysis}

The relative contributions in ecosystem services that came from different tree species were calculated as:
Table 3 Trait distributions according to native and exotic tree species, associated with character stages in a bivariate scale

\begin{tabular}{lccccc}
\hline Traits & $N$ & Native & Exotic & $\chi^{2}$ & $P$ \\
\hline Foliage type $\left(w_{1}=0.34\right)$ & & & & & \\
$\quad$ Perennial & 94 & 19 & 75 & 121 & $<0.05$ \\
$\quad$ Deciduous & 77 & 2 & 75 & & \\
Hydric requirement $\left(w_{2}=0.29\right)$ & & & & \\
$\quad$ Reduced water demand & 55 & 10 & 45 & 26 & $>0.05$ \\
High water demand & 116 & 11 & 105 & & \\
Shade quality $\left(w_{3}=0.22\right)$ & & & & & \\
Good shade & 113 & 9 & 104 & 57 & $<0.05$ \\
Bad shade & 58 & 12 & 46 & & \\
Nodulation capability and nitrogen-fixation $\left(w_{4}=0.123\right)$ & \\
$\quad$ Yes & 23 & 5 & 18 & 22 & $>0.05$ \\
No & 148 & 16 & 132 & & \\
Fruit type $\left(w_{5}=0.023\right)$ & & & & & \\
$\quad$ Yes & 36 & 2 & 34 & 22 & $>0.05$ \\
No & 135 & 19 & 116 & & \\
\hline
\end{tabular}

$V_{i}=\sum_{i=1}^{n}\left(w_{i} \cdot C_{i}\right)$

where $V_{i}$ is the environmental valuation for the $i$ th species, $C_{i}$ is the score obtained estimated from the $i$ th criterion of environmental valuation, and $w_{i}$ is the weight of the $i$ th criterion.

We used two analyses to evaluate the $V_{i}$ between native and exotic species. First, we considered all the ecosystem services as equally important (i.e., $w_{i}=1$ ); in a second approach, we used the prioritized valuation according to weight assigned by the experts (Saaty 1980). For both cases, we compared the relative contributions in ecosystem services $\left(V_{i}\right)$ between native and exotic species using a oneway ANOVA test, with the biogeographical origin treated as independent variable, which has two levels (native and exotic origin), while the log-transformed specific environmental valuation $\left(V_{i}\right)$ was included as the dependent variable. We

Table 2 Valuation scale assigned to ecosystem services when these were confronted in pairs

\begin{tabular}{lll}
\hline Value & Definition & Explanation \\
\hline 1 & Equal importance & Two environmental services are equally demanded $(\mathrm{A}=\mathrm{B})$ \\
3 & Weak importance of one over another & Experience and judgment slightly favor one ecosystem service over another $(\mathrm{A}>\mathrm{B})$ \\
5 & Essential or strong importance & Experience and judgment strongly favor one ecosystem service over another $(\mathrm{A}>>\mathrm{B}))$ \\
7 & Demonstrated importance & An ecosystem service is strongly favored and its need is demonstrated over another $(\mathrm{A}>>>\mathrm{B})$ \\
9 & Absolute importance & The evidence favoring one ecosystem service over another is of the highest possible order of \\
& & affirmation $(\mathrm{A}>>>>\mathrm{B})$ \\
\hline
\end{tabular}

This scale was used by five Chilean academic experts that working in environmental disciplines; they had to assign a value between 1 and 9 to describe the importance assigned to one environmental service compared with other (A versus B); even values were considered intermediate between the odd ones (see multi-criteria decision analysis procedure, MCDA; Saaty 1980) 
also determined whether $V_{i}$ was associated with their spatial occupancy $\left(O_{i}\right)$ in the city, using regression analyses between these variables. As it was previously mentioned, the spatial distribution was estimated as the percentage of sites occupied by each tree species from a set of sites provided from previous sampling.

\section{Results}

We found that native and exotic tree species did not differ significantly in the ecosystem services provided to urban-dwellers, when these ecosystem services were not weighted according to their demand in Santiago $(F=1.2$; $P>0.05)$. Instead, when ecosystem service weights $\left(w_{i}\right)$ were considered, we did find statistical differences for the evaluation of ecosystem services $\left(V_{i}\right)$ provided by either native and exotic species (Fig. $1 ; F=7.1 ; P<0.01$ ). Specifically, native species showed higher levels of ecosystem contribution to citizens than did exotic species in Santiago (Fig. 1). The $V_{i}(\times 100)$ values for native species ranged between 34 and 97 (Fig. 1a), while $V_{i}$ values of exotic species were between 0 and 97 (Fig. 1b). Thirteen percent of the exotic species had $V_{i}<30$, while all native tree species had $V_{i}>30$ (Fig. 1). The worst evaluated species were Acer palmatum Thunb., Celtis australis L., Fagus sylvatica L., Ginkgo biloba L., Lagerstroemia indica (L.) Pers., Magnolia $\times$ soulangeana, and Syringa vulgaris L. $\left(V_{i}=0\right.$; Supplementary material), all of them exotic species Acacia dealbata Link, Acacia melanoxylon R.Br., Ceratonia siliqua L., and Senna candolleana (Volgel) Irw. and Barn. (all of them, exotic species except for $S$. candolleana) were the best evaluated species ( $V_{i}=97$; Supplementary material).

Valuation differences among trees were due to different weightings and character stages associated with biogeographical origin. Thus, the representation of perennial species was different between native and exotic species $\left(\chi^{2}=12.2\right.$; d.f. $=1 ; P<0.05$; Table 3$)$, with perennial species being over-represented among native trees (90.4\%) while exotic species had an equal proportion of deciduous and perennial trees (50.0\%). On the other hand, native and exotic taxa also differed in the fraction of species providing 'good' shade quality according to the foliage size and density reached in summer $\left(\chi^{2}=5.8\right.$; d.f. $=1 ; P<0.05$; Table 3 ), with $69.3 \%$ of exotic species and $42.8 \%$ of native species being categorized as good shade quality providers (Table 3). Hydric requirements, nodulation capacities, and edible-fruit production did not show statistical differences when species representation was compared between native and exotic taxa (Table 3).

We did not find a significant positive nor negative relationship between $V_{i}$ and the occupancy values $\left(O_{i}\right)$ either for native species or exotic trees (Fig. 2). The regression slopes $(m)$ and correlation indices $\left(r^{2}\right)$ did not show statistically difference from zero (Fig. 2), indicating that tree valuation and spatial distribution are currently not associated in Santiago.
Fig. 1 Frequency distributions for ecosystem services valuation $\left(100 \times V_{i}\right)$ provided by native (a) and exotic (b) tree species in Santiago, Chile

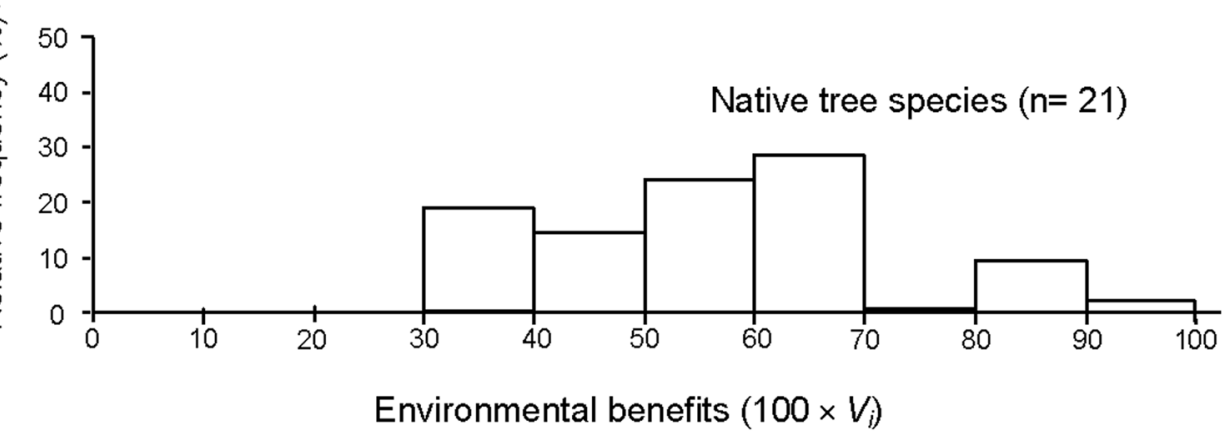

$\frac{\text { B }}{2}$

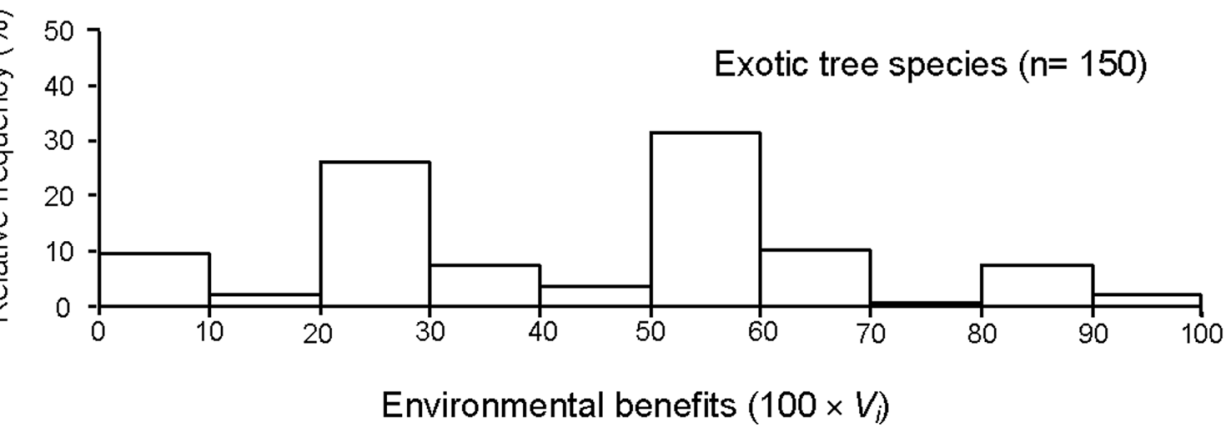


Fig. 2 Linear regressions between tree valuation $\left(V_{i}\right)$ and species occupancy in Santiago (Chile); open circles correspond to native tree species, and black circles to exotic trees. No significant slopes $(m)$ and correlation indices $(r)$ were found (all of them $P>0.05$ )

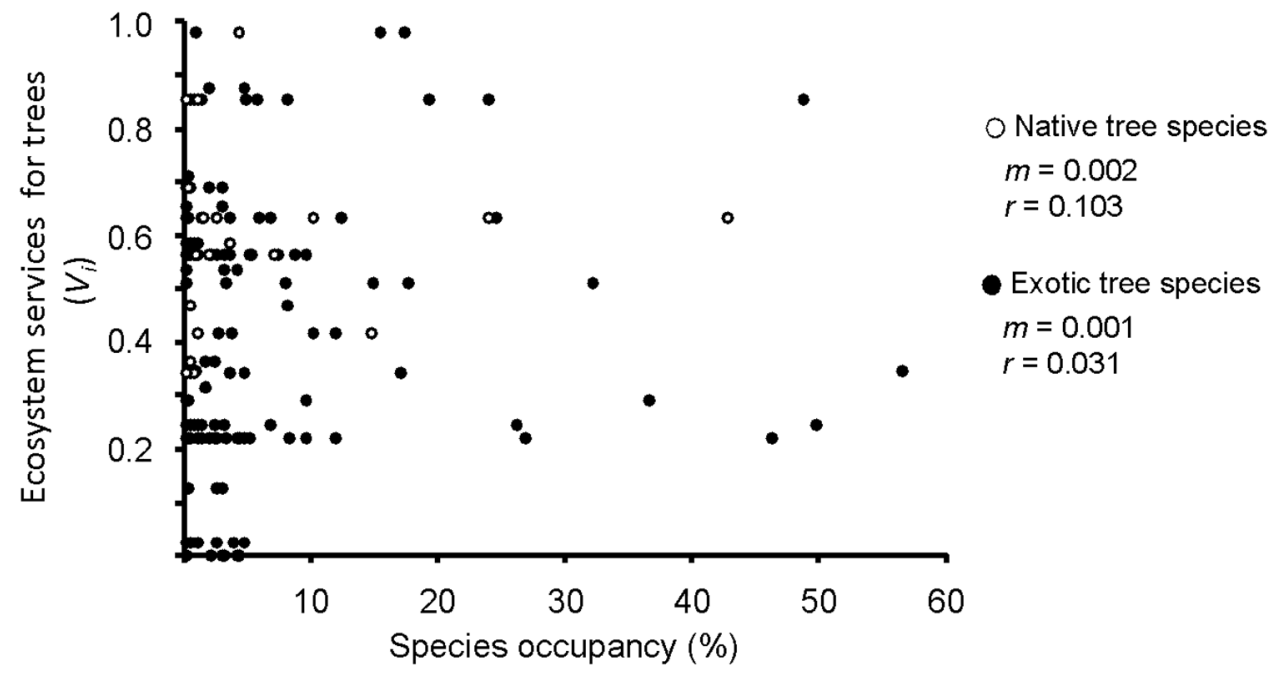

\section{Discussion}

Although several studies have analyzed the role of urban trees and the ecosystem services they provide to urbandwellers (Livesley et al. 2016), to our knowledge this is the first article that quantitatively compares the condition of biogeographical origin in trees (i.e., native and exotic). Our findings show that native and exotic tree species do not exhibit statistical differences in the provision of ecosystem services to urban dwellers, but when weights are ponderedaccording to prioritized demands in Santiago - the native species provide more ecosystem services than do exotic trees. These results provide valuable evidence for the ecosystem role of native trees in Santiago, contrasting with its scarce species richness and abundance (Figueroa et al. 2016; Hernández and Villaseñor 2018), a paradoxical situation that needs to be reverted. The ecosystem services provided by native tree species with evergreen foliage are multiple, temporarily persistent, and highly demanded in Santiago (Escobedo et al. 2011; Guerrero-Leiva et al. 2016).

In previous years, Santiago has been considered one of the most atmospherically polluted cities in South America (MMA 2014), this being the reason why this criterion was valued as the most important among the ecosystem services analyzed $\left(w_{i}=034\right.$; Table 1$)$. Tree species can reduce atmospheric pollution by superficial retention and stomatal adsorption in their leaves (Przybysz et al. 2014; Guerrero-Leiva et al. 2016). Atmospheric pollution in Santiago increases during the austral autumn and winter due to meteorological and geographic conditions (Guerrero-Leiva et al. 2016), period during which about $50 \%$ of the exotic tree species shed their leaves (Rodríguez-Ríos et al. 2006). In contrast, native tree species have a higher (potential) environmental contribution to pollution mitigation because $90.4 \%$ have evergreen foliage, retaining their leaves throughout the most polluted months (Escobedo et al. 2008; Guerrero-Leiva et al. 2016).

Water economy was valued as the second most important ecosystem service in Santiago (Table 1). This is especially important because cities in central Chile have undergone an extensive drought period (15 years, Garreaud et al. 2019), with climatic predictions indicating that dry conditions will be more frequent and intense in the near and far future (MMA 2014). Currently, Santiago lacks natural forests and all urban forests have been planted (Escobedo et al. 2010, 2016; Figueroa et al. 2016). Thus, trees in the urban forests of Santiago need to be watered for their survival, implying that those species with lower water requirements should be prioritized. Interestingly, according to our qualitative analysis, the native and exotic trees in Santiago do not differ in water requirements, with both groups being dominated by high water-demanding species. However, these results should be taken with caution since they come from indirect or qualitative records (ACHIPPA 2012). On one side, there is a widely shared perception that native trees require less water for their development and maintenance, nevertheless, because native species have evergreen foliage, during the winter season they need water supplement implicating an additional hydric cost that must be empirically measured.

The shade provided by tree species was of better quality among exotic than native species. Indeed, $69.3 \%$ of the exotic tree species provide good shade, while only $42.8 \%$ of the native species provide good shade. Exotic species have broader and taller foliage providing better shade quality (ACHIPPA 2012; Livesley et al. 2016) while reducing the heat-island effect (Gillner et al. 2015) during the austral summer. Foliage volume and density has been traditionally associated with interception of solar radiation and reduction of the air/soil temperature, both promoting an attenuation of temperatures during the warm season (Livesley et al. 2016). Therefore, the weight given to this criterion 
$\left(w_{i}=0.22\right)$ should be increased because the aforementioned climate change has produced extremely dry and hot summers (MMA 2017).

Nodulation capability for nitrogen-fixation and production of edible fruits were considered less important traits, but also scarcely represented among native and exotic tree species in Santiago, reaching 12\% and 24\%, respectively. These services have not been cultural or historically recognized or demanded (Hoffmann 1995; Figueroa et al. 2016; Santilli et al. 2018), and only recently have they reached some importance in Santiago (ACHIPPA 2012). On the other hand, of particular interest is the edible fruit production, because the observed pattern in Santiago contrasts with that of other tropical and South American cities (see Alvarez et al. 2015), where fruits of trees are profusely consumed by urban dwellers (Méndez 2005; CórdovaStroobandt 2013; Moro and Castro 2015). Indeed, fleshy fruits produced by urban forests in Santiago are scarcely used for consumption, rather they are considered as ornamentals (Hoffmann 1995). The most common exotic tree species with edible fruits in Santiago are Prunus spp., Citrus spp., and Malus spp., while the native maqui [Aristotelia chilensis (Mol.) Stuntz] is the most common native species. However, an important constrain for consumption of urban fruits in Santiago city is the potential contamination with particulate matter deposited in the fruit surface, or metals and other toxic compounds absorbed from the soil (Khashroom et al. 2019). In Santiago, there are no studies that have studied this phenomenon.

The lack of relationship between the ecosystem services provided by tree species $\left(V_{i}\right)$ and their spatial occupation $\left(O_{i}\right)$ is a paradoxical finding, and this pattern is applicable to both native and exotic tree species. The absence of an association between ecosystem services and spatial occupation is expected when urban afforestation rests on non-environmental criteria (Millennium Environmental Assessment 2005; Nowak and Dwyer 2007; Fisher et al. 2009; Escobedo et al. 2011; Grote et al. 2016). Currently, the Chilean legal framework (MININT 2004) establishes that municipalities are the entities responsible for selecting, planting, and maintaining public green spaces and infrastructure, but financial resources for these proposals are scarce. Most of the 32 municipalities in Santiago have tree assessment programs based on economic criteria, while others implement their afforestation plans based simply on the tree species available in nurseries (Ponce-Donoso et al. 2017).

At the global scale, the representation of native and exotic species in urban ecosystems constitutes a phenomenon of increasing attention (Alvey 2006; Aronson et al. 2014; McBride 2017). Particularly in south America, several floristic studies in cities show that richness (and abundance) of exotic species-including tree species-exceeds to native ones (Méndez-Stroobandt 2005; Córdova-Stroobandt 2013;
Gartner et al. 2015; Moro and Castro 2015; Figueroa et al. 2016; Santilli et al. 2018); these studies also reveal that the richness of exotic species (approx. 60\%) exceeds those recorded from North American, Asian, and European cities (50\% as average; see Aronson et al. 2014). As McBride (2017) suggested, this trend is due historical and ornamental criteria implemented in South America post-European colonization (McBride 2017), at the detriment of other considerations (Santilli et al. 2018), such as the provision of ecosystem services.

The question of which tree species are more appropriate for Santiago (i.e., native or exotic), should consider that natives overcome exotic species when prioritization of ecosystem services is included in the analysis. However, it is also important to recognize that this difference is not absolute because several exotic tree species in Santiago are as beneficial as native ones (see Fig. 1). In addition, selection of tree species for urban tree-planting should not only consider the city as a whole but rather focus at smaller spatial scales, such as streets, sidewalks, parks, squares, neighborhoods, etc. (McBride 2017). Indeed, the spatial scale at which afforestation are carried out constitutes a relevant condition for optimizing the environmental services provided by trees; thus, the ecosystem services provided by these plants could be better territorially exploited (Sjöman et al. 2016; Potgieter et al. 2017; Riley 2018; Vaz 2018). Nevertheless, there are at least three reasons for prioritizing native species in Santiago as a whole or in local scales. First, to increase the abundance and richness of the native tree species, which contributes to the provision of ecosystem services demanded by citizens and simultaneously, responding to urgent conservation needs (Cowling et al. 1996; Armesto et al. 2007; Dobbs et al. 2011; Figueroa et al. 2016; Santilli et al. 2018). Certainly, the growth of cities in central Chile has promoted the transformation of the natural landscape, exercising a negative impact on the abundance and distribution of native tree species (Cowling et al. 1996; Armesto et al. 2007). In fact, by far the most part of the native trees currently present in the public areas and private properties of the city have been intentionally planted (de la Maza et al. 2002; Escobedo et al. 2016; Figueroa et al. 2016; Santilli et al. 2018). For this reason, some of these urban spaces could be used for ex situ conservation for native species (Miller and Hobbs 2002). Second, planting native trees improves the ecological integration between Santiago and the peri-urban landscape; this especially responds to future climatic scenarios of dry and hot conditions during summer (McCarthy et al. 2010; Ellison et al. 2017) and high atmospheric pollution events during winter (MMA 2017). This is closely related to the need to mitigate atmospheric pollution between autumn and winter, when this ecosystem service is the most demanded (Préndez 2011; Guerrero et al. 2016). Finally, tree selection for urban forests demands an evaluation of environmental 
"disservice" (Nowak and Dwyer 2007; Lyytimäki et al. 2008; Lyytimäki and Sipilä 2009; Dobbs et al. 2011), not included in the present study. In Santiago, two types of environmental tree disservices have been recognized as important: the emission of allergen pollen (Mardones et al. 2011; Criollo et al. 2016) and that of volatile organic compounds (VOC) (Préndez et al. 2013; Egas et al. 2018). Although evidence is scarce for most of the tree species in Santiago city, studies have recognized exotic tree species as more disadvantageous than native trees. Indeed, pollen of exotic trees is known to be highly allergenic to Santiago's inhabitants (e.g., Platanus spp., Populus spp.) and VOC emissions (e.g., Acacia dealbata, Betula pendula Roth, Melia azedarach L., Olea europaea L., Prunus spp., Robinia pseudoacacia L.) (Préndez et al. 2013, 2014; Criollo et al. 2016; Egas et al. 2018).

In conclusion, when native and exotic tree species are compared considering the environmental needs for Santiago, the ecosystem services provided by native tree species overcome those provided by exotic ones. Additionally, the spatial representation (i.e., occupancy) of the tree species in Santiago does not exhibit relationship with ecosystem services that they may potentially provide. Thus, we suggest emphasizing the contribution of ecosystem services as criteria to select tree species in Santiago, prioritizing the planting of native species.

Supplementary Information The online version contains supplementary material available at https://doi.org/10.1007/s00468-021-02144-5.

Acknowledgements Authors were supported by DICYT 022043 AYUDANTE and ANID PIA/BASAL FB0002.

Open Access This article is licensed under a Creative Commons Attribution 4.0 International License, which permits use, sharing, adaptation, distribution and reproduction in any medium or format, as long as you give appropriate credit to the original author(s) and the source, provide a link to the Creative Commons licence, and indicate if changes were made. The images or other third party material in this article are included in the article's Creative Commons licence, unless indicated otherwise in a credit line to the material. If material is not included in the article's Creative Commons licence and your intended use is not permitted by statutory regulation or exceeds the permitted use, you will need to obtain permission directly from the copyright holder. To view a copy of this licence, visit http://creativecommons.org/licenses/by/4.0/.

\section{References}

ACHIPPA (2012) Guía de arborización urbana: Especies para la Región Metropolitana, Santiago de Chile. Asociación Chilena de Profesionales del Paisaje, Santiago, p 128

Alvarado A, Bandini A, Gajardo F (2013) Árboles urbanos de Chile: Guía de reconocimiento. Corporación Nacional Forestal. Santiago de Chile, p 376

Álvarez IA, Gallo BC, Monteiro-Garçon EA, Tadatomo-Oshiro O (2015) Street tree inventory of Campinas, Brazil: an instrument for urban forestry management and planning. Arboric Urban for 41:233-244

Alvey A (2006) Promoting and preserving biodiversity in the urban forest. Urban for Urban Green 5:195-201

Armesto JJ, Arroyo MTK, Hinojosa LF (2007) The mediterranean environment of central Chile. In: Veblen TT, Young KR, Orme AR (eds) The physical geography of South America. Oxford University Press, pp 184-199

Aronson MFJ, La Sorte FA, Nilon CH, Katti M, Goddard MA, Lepczyk CA, Warren PS, Williams NSG, Cilliers S, Clarkson B, Dobbs C, Dolan C, Hedblom M, Klotz S, Kooijmans JL, Kühn I, MacGregor-Fors I, McDonnell M, Mörtberg U, Pyšek P, Siebert S, Sushinsky J, Werner P, Winter M (2014) A global analysis of the impacts of urbanization on bird and plant diversity reveals key anthropogenic drivers. Proc Royal Soc B 281:20133330

Belton V, Stewart TJ (2002) Multiple criteria decision analysis: an integrated approach. Kluwer Academic Publishers, Massachusetts

Capotorti G, del Vico E, Lattanzi E, Tilia A, Celesti-Grapow L (2013) Exploring biodiversity in a metropolitan area in the Mediterranean region: the urban and suburban flora of Rome (Italy). Plant Biosyst 147:174-185

Casanoves F, Pla L, Di Rienzo JA (2011) Valoración y análisis de la diversidad funcional y su relación con los servicios ecosistémicos. Centro Agronómico Tropical Investigación Enseñanza, Serie Tec 384:1-119

CEPALSTAT (2020). https://www.estadisticascepalorg/cepalstat/ WEB_CEPALSTAT/estadisticasIndicadoresasp?idioma $=\mathrm{i}$ (Accessed, April 2020)

Conway TM, Almas AD, Coore D (2019) Ecosystem services, ecological integrity, and native species planting: how to balance these ideas in urban forest management? Urban for Urban Green $41: 1-5$

Córdova-Stroobandt KL (2013) Caracterización de la biodiversidad urbana en la cuenca central de Cochabamba, Bolivia. Acta Nova 6:94-121

Cowling RM, Rundel PW, Lamont BB, Kalin-Arroyo M, Arianoutsou M (1996) Plant diversity in mediterranean-climate regions. Trends Ecol Evol 11:362-366

Criollo C, Assar R, Cáceres D, Préndez M (2016) Arbolado urbano, calidad del aire y afecciones respiratorias en seis comunas de la provincia de Santiago, Chile. Rev Chil De Enfermedades Respir 32:77-86

de la Maza C, Hernández J, Bown H, Rodríguez M, Escobedo F (2002) Vegetation diversity in the Santiago de Chile urban ecosystem. Arboric J 26:347-357

Dearborn DG, Kark S (2010) Motivations for conserving urban biodiversity. Conserv Biol 24:432-440

Diaz S, Cabido M (2001) Vive la Difference: plant functional diversity matters to ecosystem processes. Trends Ecol Evol 16:646-655

Dobbs C, Escobedo FJ, Zipperer WC (2011) A framework for developing urban forest ecosystem services and goods indicators. Landsc Urban Plan 99:196-206

dos Santos AR, da Rocha CFD, Bergallo HG (2010) Native and exotic species in the urban landscape of the city of Rio de Janeiro, Brazil: density, richness, and arboreal deficit. Urban Ecosyst 13:209-222

DWUA (Demographia World Urban Areas) (2019). Demographia World Urban Areas, 15th Annual Edition 2019. http://www. demographiacom/db-worldua.pdf

Egas C, Naulin PI, Préndez M (2018) Contaminación urbana por material particulado y su efecto sobre las características morfoanatómicas de cuatro especies arbóreas de Santiago de Chile. Inf Tecnol 29:111-118

Ellison D, Morris CE, Locatelli B, Sheil D, Cohen J, Murdiyarso D, Sullivan CA (2017) Trees, forests and water: cool insights for a hot world. Glob Environ Change 43:51-61 
Escobedo FJ, Nowak DJ, Wagner JE, de la Maza CL, Rodríguez M, Crane DE, Hernández J (2006) The socioeconomics and management of Santiago de Chile's public urban forests. Urban for Urban Green 4:105-114

Escobedo FJ, Wagner JE, Nowak DJ, de la Maza CL, Rodriguez M, Crane DE (2008) Analyzing the cost-effectiveness of Santiago, Chile's policy of using urban forests to improve air quality. J Environ Manage 86:148

Escobedo F, Varela S, Zhao M, Wagner JE, Zipperer MW (2010) Analyzing the efficacy of subtropical urban forests in offsetting carbon emissions from cities. Environ Sci Policy 13:362-372

Escobedo FJ, Kroeger T, Wagner JE (2011) Urban forest and pollution mitigation: analyzing ecosystem services and disservices. Environ Pollut 159:2078-2087

Escobedo FJ, Palmas-Perez S, Dobbs C, Gezan S, Hernandez J (2016) Spatio-temporal changes in structure for a Mediterranean urban forest: Santiago, Chile 2002 to 2014. Forests 7:121

Figueroa JA, Teillier S, Guerrero-Leiva N, Ray-Bobadilla C, Rivano S, Saavedra D, Castro SA (2016) Vascular flora in public spaces of Santiago, Chile. Gayana Bot 73:85-103

Fisher RK, Turner RK, Morling P (2009) Defining and classifying ecosystem services for decision making. Ecol Econ 68:643-653

Gaertner M, Wilson JRU, Cadotte MW, MacIvor JS, Zenni RD, Richardson DM (2017) Non-native species in urban environments: patterns, processes, impacts and challenges. Biol Invasions 19:3461-3469

Garreaud RD, Boisier JP, Rondanelli R, Montecinos A, Sepúlveda HH, Veloso-Aguila D (2019) The central Chile mega drought (20102018): a climate dynamics perspective. Int J Climatol 1:1-19

Gartner E, Rojas G, Castro SA (2015) Compositional patterns of ruderal herbs in Santiago, Chile. Gayana Bot 72:192-202

Gillner S, Vogt J, Tharang A, Dettmann S, Roloff A (2015) Role of street trees in mitigating effects of heat and drought at highly sealed urban sites. Landsc Urban Plan 143:33-42

Golden BL, Wasil EA, Harker PT (1989) The analytic hierarchy process: applications and studies. Springer-Verlag, Berlin

Gómez-Baggethun E, Barton DN (2013) Classifying and valuing ecosystem services for urban planning. Ecol Econ 86:235-245

Grande-Ortiz MA, Ayuga-Téllez E, Contato-Carol ML (2012) Methods of tree appraisal: a review of their feature sand application possibilities. Arboric Urban for 38:130-140

Grote R, Samson R, Alonso R, Amorim JH, Cariñanos P, Churkina G, Calfapietra C (2016) Functional traits of urban trees: air pollution mitigation potential. Front Ecol Environ 14:543-550

Guerrero-Leiva N, Castro SA, Rubio MA, Ortiz-Calderón C (2016) Retention of atmospheric particulate by three woody ornamental species in Santiago. Chile Water Air Soil Pollut 227:435

Güneralp B, McDonald R, Fragkias M, Goodness J, Marcotullio P, Seto K (2013) Urbanization forecasts, effects on land use, biodiversity, and ecosystem services. In: Elmqvist T, Fragkias M, Goodness J, Güneralp B, Marcotullio PJ, McDonald RI, Parnell S, Schewenius M, Sendstad M, Seto KC, Wilkinson C (eds) Urbanization, biodiversity and ecosystem services: challenges and opportunities. Springer, Netherlands, pp 437-452

Hoffmann A (1995) El arbolado urbano en Chile Ediciones Fundación Claudio Gay. Santiago de Chile, p 255

Jaksic FM, Castro SA (2020) Biological invasions in the South American Anthropocene: global causes and local impacts. Springer International Publishing

James P, Tzoulas K, Adams MD, Barber A, Box J, Breuste J, Elmqvist T, Frith M, Gordon C, Greening KL, Handley J, Haworth S, Kazmierczak AE, Johnston M, Korpela K, Moretti M, Niemela J, Pauleit S, Roe MH, Sadler JP, Thompson CW (2009) Towards an integrated understanding of green space in the European built environment. Urban for Urban Green 8:65-75
Kattge J, Díaz S, Lavorel S, Prentice IC (2011) TRY: a global database of plant traits. Glob Chang Biol 17:2905-2935

Khashroom AO, Saewan SA, George SS, Hamad HJ (2019) Chemical and microbial environmental contaminants in fruits and vegetables and their effects on health: a mini review. IOSR J Environ Sci Toxicol Food Technol 13:70-76

La Sorte FA, McKinney ML (2006) Compositional similarity and the distribution of geographic range size for assemblages of native and non-native species in urban floras. Divers Distrib 12:679-686

Livesley SJ, McPherson EG, Calfapietra C (2016) The urban forest and ecosystem services: Impacts on urban water, heat, and pollution cycles at the tree, street, and city scale. J Environ Qual 45:119-124

Luebert F, Pliscoff P (2006) Sinopsis bioclimática y vegetacional de Chile Santiago de Chile. Editorial Universitaria, Santiago

Lyytimäki J (2015) Ecosystem disservices: embrace the catchword. Ecosyst Serv 12:136

Lyytimaki J, Sipila M (2009) Hopping on one leg-the challenge of ecosystem disservices for urban green management. Urban for Urban Green 8:309-315

Lyytimäki J, Petersen LK, Normander B, Bezák P (2008) Nature as a nuisance? Ecosystem services and disservices to urban lifestyle. Environ Sci 5:161-172

Mardones P, Donoso G, Rocha R, Córdova A, Grau A (2011) Caracterización y registro del polen atmosférico en la ciudad de Temuco. Rev Chil Enfermedades Respir 27:7-15

McBride JR (2017) The world's urban forest: history, composition, design, function and management. Springer, p 266

McCarthy HR, Pataki DE (2010) Drivers of variability in water use of native and non-native urban trees in the Greater Los Angeles area. Urban Ecosyst 13:393-414

McPhee J, Cortés G, Rojas M, García L, Descalzi A, Vargas L (2014) Downscaling climate changes for Santiago: What effects can be expected? In: Krellenberg K, Hansjürgens B (eds) Climate adaptation Santiago. Springer-Verlag, Berlin Heidelberg, pp 19-41

Méndez-Stroobandt E (2005) Flora y vegetación del centro urbano de Luján de Cuyo, Mendoza (Argentina). Rev Fac Cienc Agrar 37:67-74

Millennium Ecosystem Assessment (2005) Ecosystems and human well-being: Synthesis. Island Press, Washington

Miller JR, Hobbs RJ (2002) Conservation where people live and work. Conserv Biol 16:330-337

MININT (Ministerio del Interior y Seguridad Píublica; CL) (2004). Subsecretaria de Desarrollo Regional y Administrativo Ley No. 18695 Orgánica Constitucional de Municipalidades Consultado 18 oct 2007 Disponible en http://www.subderegovcl/1510/articles-65813 recurso_1doc

MMA (Ministerio del Medio Ambiente; CL) (2014). Planes de Descontaminación Atmosférica Estrategia 2014-2018. https://www. mmagobcl/planes-de-descontaminacion-atmosferica-estrategia2014-2018/ (in Spanish)

MMA (Ministerio del Medio Ambiente; CL) (2017). Plan de Acción Nacional de Cambio Climático 2017-2022. https://www.mmago bcl/wp-content/uploads/2017/07/plan_nacional_climatico_2017_ $2 \mathrm{pdf}$

Moro MF, Castro ASF (2015) A check list of plant species in the urban forestry of Fortaleza, Brazil: where are the native species in the country of megadiversity? Urban Ecosyst 18:47-71

Mustajokia J, Saarikoskia H, Beltonb V, Hjerppea T, Marttunen M (2020) Utilizing ecosystem service classifications in multi-criteria decision analysis: experiences of peat extraction case in Finland. Ecosyst Serv 41:10149

Myers N, Mittermeier RA, Mittermeier CG, da Fonseca GAB, Kent J (2000) Biodiversity hotspots for conservation priorities. Nature 403:853-858 
Nowak DJ, Dwyer JF (2007) Understanding the benefits and costs of urban forest ecosystems. In: Kuser J (ed) Urban and community forestry in the Northeast. Springer, New York, pp 25-46

Núñez-Florez R, Pérez-Gómez U, Fernández-Méndez F (2019) Functional diversity criteria for selecting urban trees. Urban for Urban Green 38:251-266

Oldfield EE, Wood SA, Palm CA, Bradford MA (2015) How much SOM is needed for sustainable agriculture? Front Ecol Environ 13:527

Panagopoulos T, González-Duque JA, Bostenaru DM (2016) Urban planning with respect to environmental quality and human wellbeing. Environ Pollut 208:137-144

Pauchard A, Barbosa O (2013) Regional assessment of Latin America: rapid urban development and social economic inequity threaten biodiversity hotspots. In: Elmqvist T, Fragkias M, Goodness J, Güneralp B, Marcotullio PJ, McDonald RI, Parnell S, Schewenius $\mathrm{M}$, Sendstad M, Seto KC, Wilkinson C (eds) Urbanization, biodiversity and ecosystem services: challenges and opportunities. Springer, Dordrecht, pp 589-608

Ponce-Donoso M, Vallejos-Barra O, Escobedo FJ (2017) Appraisal of urban trees using twelve valuation formulas and two appraiser groups. Arboriculture Urban Forestry 43:72-82

Potgieter LJ, Gaertner M, Kueffer C, Larson BMH, Livingstone S, O'Farrell P, Richardson DM (2017) Alien plants as mediators of ecosystem services and disservices in urban systems: a global review. Biol Invasions 19:3571-3588

Préndez M, Alvarado G, Serey I (2011) Some guidelines to improve the air quality management of Santiago, Chile. In: Mazzeo N (ed) Air quality monitoring, assessment and management. Intech publish, pp 305-328

Préndez M, Corada K, Morales J (2013) Natural organic compounds from the urban forest of the Metropolitan Region, Chile: Impact on air quality. In: Chetehouna K (ed) Volatile organic compounds: emission, pollution and control. Bourges Higher School of Engineering, Bourges, pp 103-141

Préndez M, Carvajal V, Corada K, Morales J, Alarcón F, Peralta H (2014) Biogenic volatile organic compounds from the urban forest of the Metropolitan Region, Chile. Environ Pollut 183:143-150

Przybysz A, Sæbø A, Hanslin HM, Gawrońskia SW (2014) Accumulation of particulate matter and trace elements on vegetation as affected by pollution level, rainfall and the passage of time. Sci Total Environ 481:360-369

Riley C, Herms DA, Gardiner MM (2018) Exotic trees contribute to urban forest diversity and ecosystem services in inner-city Cleveland, OH. Urban for Urban Green 29:367-376
Rodríguez-Ríos R, Ruíz E, Elissetche JP (2006) Arboles en Chile. Editorial Universidad de Concepción, Concepción

Roy S, Byrne J, Pickering C (2012) A systematic quantitative review of urban tree benefits, costs, and assessment methods across cities in different climatic zones. Urban for Urban Green 11:351-363

Saaty TL (1980) The analytic hierarchy process. McGraw-Hill, New York

Sæbø A, Benedikz T, Randrup TB (2003) Selection of trees for urban forestry in the Nordic countries. Urban for Urban Green 2:101-111

Sagoff M (2005) Do non-native species threaten the natural environment? J Agric Environ Ethics 18:215-236

Sagoff M (2011) The quantification and valuation of ecosystem services. Ecol Econ 70:497-502

Santilli L, Castro SA, Figueroa JA, Guerrero N, Ray C, Romero-Mieres M, Rojas G, Lavandero N (2018) Exotic species predominates in the urban woody flora of central Chile. Gayana Bot 75:568-588

Sjöman H, Morgenroth J, Deak-Söjman J, Sæbø A (2016) Diversification of the urban forest- can we afford to exclude exotic tree species? Urban for Urban Green 18:237-241

Soto JR, Escobedo FJ, Khachatryan H, Adams DC (2018) Consumer demand for urban forest ecosystem services and disservices: examining trade-offs using choice experiments and best-worst scaling. Ecosyst Serv 29:31-39

Tedersoo L, Laanisto L, Rahimlou S, Toussaint A, Hallikma T, Pärtel M (2017) Global database of plants with root-symbiotic fixation: NodDB. J Veg Sci 29:560-568

Tzoulas K, Korpela K, Venn S, Yli-Pelkonen V, Kaźmierczak A, Niemela J, Jamesm P (2007) Promoting ecosystem and human health in urban areas using green infrastructure: a literature review. Landsc Urban Plan 81:167-178

Vaz AS, Castro-Díez P, Godoy O, Alonso A, Vilà M, Saldaña A, Marchante H, Bayón A, Silva JS, Vicente JR, Honrado JR (2018) An indicator-based approach to analyses the effects of non-native tree species on multiple cultural ecosystem services. Ecol Indic $85: 48-56$

Watson G (2002) Comparing formula methods of tree appraisal. J Arboric 28:11-18

Publisher's Note Springer Nature remains neutral with regard to jurisdictional claims in published maps and institutional affiliations. 